\title{
PELAKSANAAN PEMBERIAN KREDIT PADA PT. BANK PERKREDITAN RAKYAT DHARMA NAGARI DHARMASRAYA
}

\author{
Naurah Rohadatul Aisyi, Ratna Widayati \\ Akademi Keuangan Perbankan "Pembangunan" (AKBP) Padang \\ Naurahrohadatu185@gmail.com
}

\begin{abstract}
The purpose of this study was conducted to find out how the implementation of credit provided by PT. Rural Bank Dharma Nagari. In analyzing data, the author uses qualitative data analysis as a research method that explains descriptively. In this study, it can be concluded that in giving credit to prospective debtors, PT. BPR Dharma Nagari Dharmasraya provides procedures that must be met by prospective debtors, namely through the stages of granting credit. The stages of granting credit are the stages of the application, the stages of credit analysis, the stage of credit approval, the stage of the agreement or credit agreement and the disbursement of credit. With the signing of the contract, the debtor must pay back or pay off the loan given by the bank.
\end{abstract}

Keywords : Granting credit, edited with problems

\section{PENDAHULUAN}

Bank merupakan lembaga keuangan yang kegiatannya tidak hanya menghimpun dana dan menyalurkan kembali kepada masyarakat melainkan memberikan berbagai fasilitas perbankan, selain itu juga untuk memberikan kepuasan kebutuhan kredit dalam berbagai cara (Ayuanggraini, Rahayu, \& Husaini, 2015)

Perbankan adalah salah satu penggerak perekonomian suatu negara, karena mempunyai fungsi intermediasi sebagai perantara pihak yang kelebihan dana dengan pihak kekurangan dana. Fungsi ini akan berjalan dengan baik apabila masyarakat memiliki kepercayaan terhadap bank (Hardi \& Fernos, 2017)

Bank juga lembaga keuangan yang berfungsi sebagai perantara keuangan. Bank menerima simpanan uang dari masyarakat kemudian menyalurkannya kembali dalam bentuk kredit. Penyaluran kredit memungkinkan dilakukannya investasi, distribusi, juga konsumsi barang dan jasa, mengingat semua kegiatan tersebut selalu berkaitan dengan penggunaan uang (Pratama, 2010).

Menurut pasal 1 ayat 2 Undang-Undang No. 10 tahun 1998 tentang perbankan menyebutkan bahwa :"Bank adalah badan usaha yang menghimpun dana dari masyarakat dalam bentuk simpanan, dan 
menyalurkannya dalam bentuk kredit atau bentuk lainnya dalam rangka meningkatkan taraf hidup rakyat banyak". Bank mempunyai peranan penting dalam menunjang dan meningkatkan taraf hidup masyarakat terutama dalam bidang perkreditan.

Menurut pasal 21 ayat 11 Undang-Undang No. 10 Tahun 1998 tentang perbankan, kredit adalah penyediaan uang atau tagihan yang dapat dipersamakan dengan itu, berdasarkan persetujuan atau kesepakatan pinjam meminjam antara bank dengan pihak lain, yang mewajibkan pihak peminjam melunasi utangnya setelah jangka waktu tertentu dengan pemberian bunga.

Bank pada hakikatnya merupakan lembaga intermediasi dimana satu sisi menampung dana dari masyarakat dalam bentuk tabungan dan di sisi lain bank menyalurkannya kepada masyarakat dalam bentuk kredit. Sebagai pemberi kredit, bank wajib menetapkan suatu kebijakan perkreditan agar tetap memelihara keseimbangan antara keinginan memperoleh keuntungan dan menjamin luasnya semua kredit yang disalurkan.

Berdasarkan uraian diatas, penulis tertarik untuk melakukan penelitian yang berjudul "Pelaksanaan Pemberian Kredit Pada Pt. Bank Perkreditan Rakyat Dharma Nagari Dharmasraya"

\section{METODE PENELITIAN}

Dalam menganalisa data, metode yang digunakan yaitu berupa metode data Kualitatif. Metode kualitatif yaitu data dari penjelasan kata yang tidak dapat dianalisis dalam bentuk bilangan atau angka. Dalam penelitian, data kualitatif berupa gambaran mengenai objek penelitian, yang memberikan dan menunjukkan kualitas objek penelitian yang dilakukan.

\section{HASIL DAN PEMBAHASAN}

Dalam melakukan pelaksanaan pemberian kredit pada PT. Bank Perkreditan Rakyat Dharma Nagari Dharmasraya melalui tahapan atau prosedur pemberian kredit berikut ini :

1. Prosedur Pemberian Kredit

Prosedur pemberian kredit pada PT. Bank Perkreditan Rakyat Dharma Nagari sebagai berikut

a. Nasabah mengajukan permohonan kredit secara tertulis dengan mengisi formulirpermohonan kredit dan melampirkan : Fotocopy Suami istri, Kartu Keluarga, Surat Nikah,Keterangan Usaha, serta Fotocopy agunan/jaminan surat berharga, BPKB Kendaraan, atau surat berharga bilyet deposito.

b. Analisa Kredit

Setelah melengkapi persyaratan dan mengisi semua data permohonan kredit, pihak bank akan melakukan analisa kredit terlebih dahulu.

Analisa yang digunakan pada PT. BPR Dharma Nagari Dharmasraya berpedoman pada prinsip 5C, yaitu :

1) Character, yaitu melihat bagaimana watak atau latar belakang calon nasabah yang mengajukan permohonan kredit,ini diketahui dari wawancara atau survei lapangan ke masyarakat dilingkungan sekitarnya, apakah calon nasabah memiliki tindak kriminal atau 
kebiasaan buruk dalam keuangan, seperti tidak melunasi pinjaman. Character dilihat juga melalui Bank checking. Bank Checking adalah laporan yang dikeluarkan oleh Bank Indonesia yang berisi riwayat pinjaman seorang nasabah kepada bank atau lembaga keuangan non bank, apakah riwat kreditnya bagus atau buruk semua terdata dalam Sistem Informasi Debitur (SID) Bank Indonesia.

2) Capacity, yaitu kemampuan calon nasabah dalam membayar kreditnya. Capacity ini dilihat dan dinilai dari bagaimana calon nasabah tersebut menjalankan usahanya, atau dari penghasilan yang diterimanya apakah mampu atau cukup untuk membayar kredit, jika pihak bank menilai calon nasabah tidak mampu, maka besar kemungkinan permohonan kreditnya ditolak.

3) Capital, yaitu modal yang dimiliki calon debitur, capital ini berlaku khusus untuk calon nasabah yang meminjam untuk usaha atau bisnisnya. Pihak bank akan menilai melalui laporan keuangan usaha yang dijalankan, untuk dijadikan acuan apakah memang layak diberikan atau tidak.

4) Collateral, yaitu jaminan yang diberikan calon nasabah saat melakukan permohonan kredit, jaminan ini bisa berupa barang bergerak maupun barang tidak bergerak, jaminan ini akan menjadi pegangan bagi bank. Jumlah harga jaminan atau agunan lebih besar dibandingkan kredit yang diberikan.

5) Condition Of Economy, yaitu kondisi perekonomian nasabah. Jika perekonomian nasabah sedang tidak baik atau usahanya tidak menjanjikan, pihak bank akan mempertimbangkan kembali untuk memberikan kredit.

c. Persetujuan Kredit

Setelah analisis selesai, barulah pihak kredit akan mempresentasikan hasil analis dihadapan komite kredit. Kemudian pihak komite kredit akan menentukan apakah kredit disetujui atau ditolak sesuai dengan ketentuan yang berlaku. Jika kredit disetujui maka akan berlanjut ke tahap selanjutnya.

d. Akad Kredit

Setelah kredit disetujui maka akan dilakukan penandatanganan akad kredit oleh kedua belah pihak. Kemudian barulah pengikatan Agunan (APHT, SKMHT, Fidusia). APHT adalah Akta Pemberian Hak Tanggungan, sedangkan SKMHT adalah Surat Kuasa Membebankan Hak Tanggungan. APHT/SKMHT dibuat apabila jaminan yang diberikan untuk menjamin pelunasan kredit kepada bank berupa tanah yang memenuhi syarat sebagai obyek hak tanggungan, yaitu tanah tersebut berstatus hak milik, hak guna bangunan, guna usaha atau hak pakai yang mempunyai sifat dapat dipindah tangankan. Fidusia yaitu jenis agunan yang dikategorikan benda bergerak, contohnya mobil.

e. Proses Pencairan Dana

Setelah penandatanganan akad dan pengikatan agunan selesai, barulah kredit dapat dicairkan kepada nasabah, dengan syarat memiliki rekening atau membuka rekening baru dibank tersebut. 


\section{f. Pengarsipan}

Administrator kredit akan melakukan penyimpanan file kredit \& penyimpanan agunan kredit didalam lemari anti api.

g. Monitoring

Pihak bank akan mengontrol kelancaran usaha dan kelancaran angsuran kredit nasabah mulai dari pencairan sampai pelunasan.

h. Penyelesaian Kredit Bermasalah

Apabila terdapat kredit yang bermasalah maka pihak kreditur akan melakukan penyelesaian dengan sistem kekeluargaan, jika sistem kekeluargaan tidak bisa menyelesaikan masalah, maka akan diberi surat peringatan. Jika surat peringatanpun tidak menyelesaikan masalah, maka akan dilakukan penjualan agunan secara sukarela atau melalui lelang.

2. Perkembangan PemberianKredit

Perkembangan pemberian kredit di PT. BPR Dharma Nagari dapat dilihat melalui tabel berikut.

Tabel 1

Perkembangan Pemberian Kredit

pada PT. BPR Dharma Nagari Dharmasraya dari tahun 2015 sampai tahun 2018.

\begin{tabular}{|c|c|c|l|l|}
\hline \multicolumn{1}{|c|}{ Jenis Kredit } & \multicolumn{1}{|c|}{$\mathbf{2 0 1 5}$} & \multicolumn{1}{|c|}{$\mathbf{2 0 1 6}$} & \multicolumn{1}{|c|}{$\mathbf{2 0 1 7}$} & \multicolumn{1}{c|}{$\mathbf{2 0 1 8}$} \\
\hline 1. Modal kerja & 9.096 .892 & 8.624 .545 & 6.799 .209 & 6.009 .575 \\
\hline 2. Investasi & 9.088 .012 & 8.773 .875 & 10.112 .475 & 9.454 .244 \\
\hline 3. Konsumtif & 1.839 .235 & 2.650 .847 & 3.191 .223 & 3.066 .996 \\
\hline Jumlah & 20.024 .139 & 20.049 .267 & 20.102 .907 & 18.530 .815 \\
\hline
\end{tabular}

Sumber: PT. Bank Perkreditan Rakyat Dharma Nagari Dharmasraya

Dari tabel diatas dapat dilihat bahwa kredit modal kerja mengalami penurunan dari tahun ke tahun yaitu, dari tahun 2015 jumlah kredit modal kerja sebesar Rp. 9.096.892,-. Tahun 2016 mengalami penurunan sebesar Rp. 472.347,-- menjadi Rp. 8.624.545,tahun 2017 juga mengalami penurunan sebesar Rp. 1.825.336 menjadi Rp. 6.779.209,-. kemudian tahun 2018 kembali mengalami penurunan sebesar Rp. 789.634,- menjadi Rp. 6.009.575. kredit Investasi juga mengalami penurunan dari tahun 2015 ke tahun 2016 yaitu, tahun 2015 jumlah kredit investasi sebesar Rp. 9.088.012,-. Ditahun 2016 kredit investasi mengalami penurunan sebesar Rp. 314. 137,- menjadi Rp. 8.773.875,-. Tetapi pada tahun 2017 kredit investasi mengalami peningkatan sebesar Rp. 1.338.600,- menjadi Rp. 10.112.475,-. Namun pada tahun 2015 kembali mengalami penurunan sebesar Rp. 658.231,- menjadi Rp. 9.454.244,-. Kredit Konsumtif mengalami peningkatan dari tahun 2015 sampai tahun 2017 yaitu, tahun 2015 jumlah kredit konsumtif sebesar Rp. 1.839.235,-. Pada tahun 2016 kredit konsumtif mengalami peningkatan sebesar Rp. 811.612,- menajdi Rp. 2.650. 847,-. Tahun 2017 juga mengalami peningkatan sebesar Rp. 540.376,- menjadi Rp 3.191.223,-. Tetapi pada tahun 2018 kredit konsumtif mengalami penurunan sebesr Rp. 
124.227 menjadi Rp. 3.966.996,-- Sehingga dapat disimpulkan bahwa Kredit mengalami penurunan yang disebabkan oleh adanya penurunan tingkat pendapatan masyarakat yang pada umumnya petani karet dan sawit, ini disebabkan oleh rendahnya harga jual karet dan sawit. Dan Kredit yang mengalami peningkatan disebabkan oleh banyaknya nasabah yang membutuhkan dana untuk usaha yang dijalankannya.

3. Kredit BermasalahDan Cara Mengatasinya

a. Kredit bermasalah pada PT BPR Dharma Nagari Dharmasraya, dapat dilihat pada tabel Kolektibility Kredit dibawah ini:

Tabel 2

Kolektibility Credit

PT. BPR Dharma Nagari Dharmasraya

\begin{tabular}{|l|r|r|r|r|}
\hline \multicolumn{1}{|c|}{ Uraian } & \multicolumn{1}{c|}{$\begin{array}{c}\text { Posisi Des } \\
\mathbf{2 0 1 7}(\mathbf{R p})\end{array}$} & $\begin{array}{c}\text { Posisi Des } \\
\mathbf{2 0 1 8}(\mathbf{R p})\end{array}$ & $\begin{array}{c}\text { Naik/Turun } \\
\mathbf{2 0 1 8}(\mathbf{R p})\end{array}$ & $\begin{array}{c}\text { Naik/Turun } \\
\mathbf{2 0 1 8}(\mathbf{\%})\end{array}$ \\
\hline 1. Lancar & 17.343 .229 & 15.713 .103 & $(1.630 .126)$ & $-9,40$ \\
\hline $\begin{array}{l}\text { 2. Kurang } \\
\text { Lancar }\end{array}$ & 367.555 & 908.355 & 540.800 & 147,13 \\
\hline 3. Diragukan & 607.973 & 242.216 & $(365.757)$ & $-60,16$ \\
\hline 4. Macet & 1.784 .150 & 1.667 .081 & $(117.069)$ & $-6,56$ \\
\hline Total & 20.102 .907 & 18.530 .755 & $(1.572 .152)$ & $(7,82)$ \\
\hline
\end{tabular}

Sumber: PT. Bank Perkreditan Rakyat Dharma Nagari Dharmasraya

Dari tabel kolektibilitas kredit pada BPR Dharma Nagari

Dharmasraya diatas dapat dilihat bahwa kredit bermasalah dimulai dari kredit kurang lancar, pada tahun 2017 sebesar Rp. 367.555 dan tahun 2018 sebesar Rp. 908.355 mengalami kenaikan sebesar 147,13\%kenaikan ini disebabkan karena debitur terlambat membayar lebih dari 60 hari semenjak tanggal jatuh tempo,namun masih memiliki itikad baik meski kemampuan membayarnya kurang memadai.

Kredit diragukan, pada tahun 2017 sebesar Rp. 607.973 dan tahun 2018 sebesar Rp. 242.216 mengalami penurunan sebesar 60,16\% Penurunan disebabkan karena debitur masih memiliki itikad baik untuk membayar kredit walaupun mengalami keterlambatan melebihi 120 hari setelah tanggal jatuh tempo. Untuk kredit macet pada tahun 2017 sebesar Rp. 1.784.150 dan tahun 2018 sebesar Rp. 1.667.081 mengalami penurunan sebesar $6,56 \%$ penurunan disebabkankarena faktor Eksternal yang disebabkan oleh kegagalan usaha nasabah dan faktor ekonomi masyarakat yang melemah.

b. Penyelesaian Kredit Bermasalah

Penyelesaian kredit bermasalah dilakukan dengan cara sebagai berikut :

1) Memberikan peringatan atau negosiasi lewat telepon.

2) Jika cara yang pertama tidak berhasil, pihak bank akan memberikan surat peringatan tertulis kepada nasabah.

3) Jika kedua cara tersebut tidak mampu menyelesaikannya maka pihak bank akan melakukan pelelangan agunan. 


\section{SIMPULAN}

Berdasarkan pembahasan yang telah dijelaskan, maka penulis dapat menarik kesimpulan yaitu sebagai berikut :

1. Pelaksanaan pemberian kredit pada BPR Dharma Nagari Dharmasraya dimulai dari permohonan kredit sampai dengan pencairan dana.

2. Didalam pelaksanaannya jenis kredit yang disalurkan oleh BPR Dharma Nagari adalah kredit yang berdasarkan tujuan penggunaannya yang terdiri dari Kredit Modal Kerja, Investasi dan Konsumsi.

3. Kolektibilitas kredit pada BPR Dharma Nagari Dharmasraya dapat disimpulkan bahwa kredit bermasalah dimulai dari kredit kurang lancar, pada kredit ini terjadi kenaikan yangdisebabkan karena debitur terlambat membayar lebih dari 60 hari semenjak tanggal jatuh tempo,namun masih memiliki itikad baik meski kemampuan membayarnya kurang memadai.

Kredit diragukan, kredit ini terdapat penurunan disebabkan karena debitur masih memiliki itikad baik untuk membayar kredit walaupun mengalami keterlambatan melebihi 120 hari setelah tanggal jatuh tempo. Untuk kredit macet terdapat penurunan disebabkankarena faktor Eksternal yang disebabkan oleh kegagalan usaha nasabah dan faktor ekonomi masyarakat yang melemah.

\section{UCAPAN TERIMA KASIH}

Terimakasih penulis sampaikan kepada :

1. Kepada keluarga yang selalu memberikan dukungan.

2. Direktur AKBP beserta prodi AKBP yang telah memberikan kesempatan kepada penulis untuk melakukan penelitian ini.

3. Dosen Pembimbing tugas akhir yang telah memberikan arahan dan bimbingan hingga tugas akhir ini bisa terselesaikan.

4. Pimpinan PT. BPR Dharma Nagari Dharmasraya

5. Semua Pihak yang telah memberikan dukungan dan bantuannya dalam penyelesaian tugas akhir ini.

\section{DAFTARPUSTAKA}

Andriani, B., \& Susanto, R. (2019). Pengawasan Kredit PT. Bank Perkreditan Rakyat (BPR) Ophir Pasaman Barat. https://doi.org/10.31219/osf.io/aunvc

Amelia, L., \& Marlius, D. (2018). Pengendalian Kredit Dalam Upaya Menciptakan Bank Yang Sehat Pada PT. Bank Pembangunan Daerah Sumatera Barat Cabang Utama Padang. https://doi.org/10.31227/osf.io/kpc64

Ayu anggraini, R., Rahayu, S. M., \& Husaini, A. (2015). Analisis Aspek Kelayakan Pemberian Kredit Usaha Mikro dalam Upaya Mengantisipasi Terjadinya Kredit Bermasalah. Jurnal Administrasi Bisnis (JAB), 21(1), 110.

Alanshari, F., \& Marlius, D. (2018). Prosedur Pemberian Kredit KPR Pada PT. Bank Tabungan Negara (Persero) TBK Cabang Pembantu Bukittinggi. 
https://doi.org/10.31227/osf.io/rsfhc

Darmawanto, \& Fernos, J. (2019). Prosedur Pemberian Kredit Pada Bank Nagari Cabang Sijunjung. https://doi.org/10.31227/osf.io/psqfy

Hardi, J., \& Fernos, J. (2017). Analisis LDR dan NPL PT. Bank Nagari Cabang Pembantu Tarusan Kabupaten Pesisir Selatan. Osf.io, 1-10.

Pratama, D., \& Fernos, J. (2019). Prosedur Pelaksanaan Kredit Usaha Rakyat (KUR) Pada PT. Bank Nagari Cabang Padang. https://doi.org/10.31227/osf.io/ag68j

Pratama, B. A. (2010). Analisis Faktor-Faktor yang Mempengaruhi Kebijakan Penyaluran Kredit Perbankan. Tesis.

Widayati, R. (2019). Pelaksanaan Prinsip Kehati-Hatian Dalam Pemberian Kredit Konsumtif Pada Bank Nagari Cabang Siteba. https://doi.org/10.17605/OSF.IO/FZVXR

Widayati, R. (2019). Aktivitas Pemberian Kredit Komersil Pada Bank Nagari Cabang Sijunjung. https://doi.org/10.17605/OSF.IO/QTVZ9

Widayati, R. (2019). Pelaksanaan Kredit Pada Bank Perkreditan Rakyat LPN Pasar Baru Durian Sawahlunto. https://doi.org/10.17605/OSF.IO/5HPAB

Widayati, R. (2019). Aktivitas Pemberian Kredit Usaha Pada PT. Bank Perkreditan Rakyat Batang Kapas. https://doi.org/10.17605/OSF.IO/EDPN4 